\title{
How patients built up the practice of the lay homeopath Clemens von Bönninghausen. Quantitative and qualitative aspects of patient history
}

\author{
Marion Baschin (*) \\ (*) Institut für Geschichte der Medizin der Robert Bosch Stiftung, Stuttgart. \\ marion.baschin@igm-bosch.de
}

Dynamis

[0211-9536] 2011; 31 (2): 475-495
Fecha de recepción: 12 de febrero de 2010

Fecha de aceptación: 27 de julio de 2010

SUMARIO: 1.- Introduction. 2.-The homeopath and his journals. 3.-The practice. 4.-The patients. 5.-The illnesses. 6.-Conclusions.

ABSTRACT: Statistics seem to give little information about individuals' fates. With the help of patient journals, the interwoven connections between quantitative and qualitative aspects of historical research work can be shown. This example focuses on the patients who, between 1829 and 1864, built up the practice of the lay homeopath Clemens Maria Franz von Bönninghausen in Münster, Westphalia. Questions of practice, the social structure of the clientele, and the diseases Bönninghausen treated are also considered.

KEY WORDS: Homeopathy, medical practice, patient history, quantitative and qualitative analysis. PALABRAS CLAVE: Homeopatía, práctica médica, historia del paciente, análisis cuantitativo y cualitativo.

\section{Introduction $\left(^{*}\right)$}

On the 26th August 1849, Christine, a 24 year-old, went to the house of Clemens Maria Franz von Bönninghausen. She did not have a severe illness.

${ }^{*}$ ) The data presented in this paper come from my doctoral thesis which was supported by the Studienstiftung des deutschen Volkes e. V. Some of the figures have already been used in a paper given at the conference «Methods in Theory and Practice. A conference for research students in History of Medicine and Allied Sciences» which took place in London on 25th and 26th June 2009, and which gave the idea for this article. See: The Wellcome Trust Centre for the History of Medicine at UCL. Methods2009.eu [updated 2 June 2009; cited 1 August 2010]. Available from http://www.methods2009.eu/index.html. 
According to her complaints, she only had some premenstrual pains, a dry throat, and aching legs, and she was very thirsty.

Clemens von Bönninghausen was a lay homeopath who practiced in Münster in Westphalia. Although he had never studied medicine, he was allowed to treat people homeopathically thanks to an extraordinary permission granted by the Prussian king in 1843. Bönninghausen left more than 116 journals testifying to his medical practice. These records contain details about all the patients and their illnesses he had treated during his career as a lay homeopath between 1829 and 1864. These casebooks offer the opportunity to demonstrate the interwoven connections between quantitative and qualitative aspects of research work, especially in the field of patient history and the history of medical practice ${ }^{1}$.

If the history of medical practice is considered, a lot of questions arise ${ }^{2}$. How busy was the doctor? How many patients did he see during a day or a year? Who were his patients? Which illnesses did he treat? The answers to these questions partly consist of statistics reporting consultation rates per day, describing the clientele by percentages of socio-statistical features, or ranking illnesses according to their quantities. Amony all of these numbers, the individuals, the patients, who form the core of patient history, as Christine did, seem to have vanished. This article therefore shows how patients build up a medical practice. It demonstrates that there is no medical practice without sick people and their decision to see a certain healer. The research of the casebooks in this article is focused on the patients and

1. These journals are kept in the archive of the Institute for the History of Medicine of the Robert Bosch Foundation in Stuttgart (IGM). They have the signature P 1 to P 116. The initial article for research in patients and their history was: Porter, Roy. The patient's view. Doing medical history from below. Theory and Society. 1985; 14: 175-198. An overview about patient history in medical history in general is offered by Wolff, Eberhard. Perspectives on patients' history. Methodological considerations on the example of recent German-speaking literature. Canadian Bulletin of Medical History. 1998; 15: 207-228 and Eckart, Wolfgang; Jütte, Robert. Medizingeschichte. Eine Einführung. Cologne/Weimar/Vienna: Böhlau; 2007, p. 181-190. More literature concerning patients in homeopathy in Stollberg, Gunnar. Patients and homeopathy. An overview of sociological literature. In: Dinges, Martin, ed. Patients in the history of homeopathy. Sheffield: European Association for the History of Medicine and Health Publications; 2002, p. 317-329.

2. As examples for such questions see Duffin, Jacalyn. Langstaff. A nineteenth-century medical life. Toronto/Buffalo/London: University of Toronto Press; 1999; and more recently DietrichDaum, Elisabeth; Dinges, Martin; Jütte, Robert; Roilo, Christine, eds. Arztpraxen im Vergleich. 18.-20. Jahrhundert. Innsbruck/Vienna/Bolzano: Studienverlag; 2008. 
refers to the example of the journals of the lay homeopath Clemens Maria Franz von Bönninghausen ${ }^{3}$.

\section{The homeopath and his journals}

Clemens Maria Franz von Bönninghausen was born in March 1785. He studied law and later worked for Louis Napoleon, the King of The Netherlands. When Louis Napoleon abdicated in 1810, Bönninghausen returned to his home region of Westphalia. He worked there for the Prussian administration and earned his living as a member of the land registry service («Katasterkontrolleur»). He was also very interested in botany and agriculture. In 1828, he became so gravely ill that all his friends and even all the physicians he consulted thought he would not survive. So he wrote a goodbye message to a friend who was, without Bönninghausen's knowledge, also a homeopathic doctor, the very first in Westphalia. The friend advised him of possible remedies and Bönninghausen recovered. Due to this miraculous healing, Bönninghausen became interested in the healing method that saved his life, and studied it himself. In 1829 he started his first official casebook named: «Trials in Homeopathic Healing» («Homöopathische Heilungs-Versuche»). His first patient was the famous German poetess Annette von Droste-Hülshoff. More patients followed, but, as Bönninghausen had never studied medicine and was not legally approved as a physician, his treatments soon provoked an unfavourable reaction. In 1836 the Prussian Government prohibited him from practicing homeopathy, but he never stopped his work and kept on treating those who sought his

3. The casebooks of doctors are valuable indirect sources for patient history. There have only been a few works researching a medical practice through focusing on the patients. Especially: Baal, Anne van. In search of a cure. The patients of the Ghent homeopathic physician Gustave A. van den Berghe (1837-1902) [doctoral thesis]. University Amsterdam; 2004. Clemens von Bönninghausen's patient diaries have not yet been handled in this way. GijswijtHofstra, Marijke. Homeopathy's early Dutch conquests. The Rotterdam clientele of Clemens von Bönninghausen in the 1840s and 1850s. Journal of the History of Medicine and Allied Sciences. 1996; 51: 155-183 only investigates the Dutch patients. However, this is not a true representation of the patients as a whole. For further information about the research on Bönninghausen, see Baschin, Marion. Wer lässt sich von einem Homöopathen behandeln? Die Patienten des Clemens Maria Franz von Bönninghausen (1785-1864) [doctoral thesis]. University of Stuttgart; 2009, chapter 1.1. published in 2010 as Medizin, Gesellschaft und Geschichte Beihefte 37. 
help. In 1843, he was officially allowed to practice as a lay homeopath by an extraordinary permission from the Prussian King, probably thanks to the support of a nobleman who was a friend of him. However, the reasons why Bönninghausen received this authorisation remain unknown. From this point on, he offered his homeopathic treatments, in his home town of Münster in Westphalia, until he died on the 26th January $1864^{4}$.

The city of Münster was a former Hanseatic City and seat of a PrinceBishopric («Fürstbistum Münster»). In 1815, it became Prussian and was made the capital of the newly formed Province of Westphalia. The main university was, and still is, located there and offered medical studies. As such, the city had a lot of doctors and barber-surgeons, more than the average for the whole province ${ }^{5}$. That is why the inhabitants were able to choose from a variety of medical services. There, remarkably, Bönninghausen was able to have a flourishing homeopathic practice without being an educated healer.

As the evaluation of different patients' stories shows, sick people seeking help from Bönninghausen had, in most cases, already received medical help and had often consulted the homeopath after previous unsuccessful therapies. The treatments on offer ranged from self-medication with home remedies and advice from lay healers and other homeopaths, to cures from legally approved medical practitioners, such as midwives, surgeons and university doctors. Some of his patients had already stayed at hospitals or spas ${ }^{6}$.

4. All details in: Kottwitz, Friedrich. Bönninghausens Leben. Hahnemanns Lieblingsschüler. Berg am Starnberger O.-Verlag; 1985.

5. In 1849, for instance, there was one doctor for about 608 people in Münster, while in Prussia there was one doctor for about 3,000 inhabitants. In the province of Westphalia the district of Münster had one doctor for 2,141 inhabitants. Baschin, n. 3, p. 66-67 and p. 361-362. Further details concerning the medical situation and the care system: Schwanitz, Hedwig. Krankheit, Armut, Alter. Gesundheitsfürsorge und Medizinalwesen in Münster während des 19. Jahrhunderts. Münster: Aschendorff; 1990 and Teuteberg, Hans-Jürgen. Bevölkerungsentwicklung und Eingemeindungen (1816-1945). In: Jakobi, Franz-Josef, ed. Geschichte der Stadt Münster. Münster: Aschendorff; 1993, vol. 2, p. 331-386.

6. 9,851 patients ( $69.1 \%$ of the 14,266 files in the database) admitted a previous treatment. 5,568 sick people (39.0\%) named the remedies they had used before, especially sulphur or mercury cures, but china against feverish illnesses as well. 261 patients (1.8\% of all files) had experienced another homeopathic treatment. About 1,210 persons ( $8.5 \%$ of all 14,266 patients) had received allopathic treatment before. 93 patients had been to spas and 79 tried to be cured in a hospital. But obviously they were not content with the therapies they had used so far. For more and detailed information: Baschin, n. 3, chapter 4. For a description of the 
Homeopathy is a medical method developed by Samuel Hahnemann at the beginning of the nineteenth century. The principle «similia similibus curentur» is the core of this therapy. With the idea that illnesses should be treated by those remedies that, in a healthy person, invoke the very same symptoms that the patient is currently complaining about, this healing system differs completely from the accepted academic medicine, even today. The particular feature of this method is that homeopaths consider the sick person as a whole, and they are interested in every single symptom of the illness; only in this way can the right remedy be chosen. In consequence the anamnesis of a homeopathic doctor is, in most cases, very long, and entails collecting a number of details about the feelings and the actual state of the patient as well as the remedies previously resorted to in order to make him or her better ${ }^{7}$. After the anamnesis, the homeopath is able to compare the current symptoms of the sick person with the results of testing medicaments on healthy people, and to decide which «simile» should be prescribed. The medicines chosen were almost never in the pure form and original strength, but were usually administered in as small a dose as possible. This was done through diluting or potentisation. The medicaments were then supplied in

patient behaviour in the «medical market» see also Dinges, Martin. Introduction. Patients in the history of homeopathy. In: Dinges, n. 1, p. 1-32. An overview about the different possibilities for a medical treatment in Germany is offered by: Loetz, Francisca. Vom Kranken zum Patienten. «Medikalisierung» und medizinische Vergesellschaftung am Beispiel Badens 1750-1850. Stuttgart: Steiner; 1993. As to France see: Brockliss, Laurence; Jones, Colin. The medical world of early modern France. Oxford: Clarendon Press; 1997. As to Great Britain see: Porter, Roy; Porter, Dorothy. In sickness and in health. The British experience 16501850. London: Fourth Estate; 1988. Concerning available «alternative» methods: Porter, Roy: Health for sale. Quackery in England 1660-1850, Manchester: Manchester University Press; 1989; or Gijswijt-Hofstra, Marijke; Marland, Hilary; de Waardt, Hans, eds. Illness and healing alternatives in western Europe: London/New York: Routledge; 1997.

7. For the history of homeopathy and its founder see Jütte, Robert. Samuel Hahnemann. Begründer der Homöopathie. Munich: Deutscher Taschenbuchverlag 3. Auflage; 2007; Dinges, Martin, ed. Homöopathie. Patienten, Heilkundige, Institutionen von den Anfängen bis heute. Heidelberg: Haug; 1996; Dinges, Martin, ed. Weltgeschichte der Homöopathie. Länder, Schulen, Heilkundige. Munich: Beck; 1996; Schmidt, Josef. Taschenatlas Homöopathie. Grundlagen, Methodik und Geschichte. Heidelberg: Haug; 2001. For English bibliography see the Network Series of the European Association for the History of Medicine and Health, especially the volume 5: Dinges, n. 1 and Dinges, Martin. The current state of research on the history of homeopathy. In: Witt, Claudia; Albrecht, Henning, eds. New directions in homeopathy research. Advice from an interdisciplinary conference. Essen: KVC-Verlag; 2009, p. 13-41. 
the form of drops, globules, tablets or poultices. There are different levels of dilution, containing the original agent at ratios between 1:10 and 1:50,000 .

To remember all the details of the extensive anamnesis, homeopaths very soon started to keep records about their patients, and so did Bönninghausen. Between 1829 and 1864 he filled more than 116 journals with a wealth of information about every person and illness he had treated during his life as a lay homeopath. About 55 of the 116 journals were chosen for the research. In samples of five years each, they cover 20 years of his practice and represent important parts of it. Therefore, the first and last years from 1829-1833 (S 1, 1,185 patients) and 1859-1864 (S 4, 4,066 sick people) were selected. Two of the samples include years when, on the one hand, Bönninghausen treated his patients illegally (between 1839-1843 [S 2, 4,524 patients]) and, on the other, he was finally allowed to do so and was able to dedicated himself fully to his patients (between 1849 and 1853 $[\mathrm{S} \mathrm{3}, 4,491])^{9}$.

The books Bönninghausen used were pre-printed and therefore standardised. Each patient had a whole page, starting with general information about him or her, that is, name, age, community, profession and marital status.

As shown in figure 1, in the upper half of the page there is a line listing the remedies and cures already received, and the first anamnesis is also written down there. Bönninghausen even made a comment as to whether he had seen a patient in person or not. On the second half of the page there are four columns. The second is intended for the prescribed homeopathic remedies and the appointments; the third for the dose and the amount of «globules» to be taken; and the last for further remarks concerning changes in the status of the sick person, whether the symptoms improved or vanished, and even whether new complaints arose ${ }^{10}$.

8. Schmidt, n. 7, p. 65-67 on the manufacture of the medicaments.

9. More details about the homeopathic analysis: Jütte, Robert. Case taking in homeopathy in the 19th and 20th centuries. British Homeopathic Journal. 1998; 87: 39-47. Dealing with the casebooks of Bönninghausen in particular: Dinges, Martin; Holzapfel, Klaus. Von Fall zu Fall. Falldokumentation und Fallredaktion Clemens von Bönninghausen und Annette von DrosteHülshoff. Zeitschrift für klassische Homöopathie. 2004; 48: 149-167; and Gijswijt-Hofstra, n. 3. For more information concerning the selection of he journals and the methodological issues: Baschin, n. 3, chapter 2.

10. Bönninghausen also published his system in Bönninghausen, Clemens von. Das Krankenjournal. Allgemeine Homöopathische Zeitung. 1863; 67: 114-116, 121-123, 129-131, 140-141, 147-149, 163-165. 
Figure 1. Pre-printed page in Bönninghausens journals (1863)

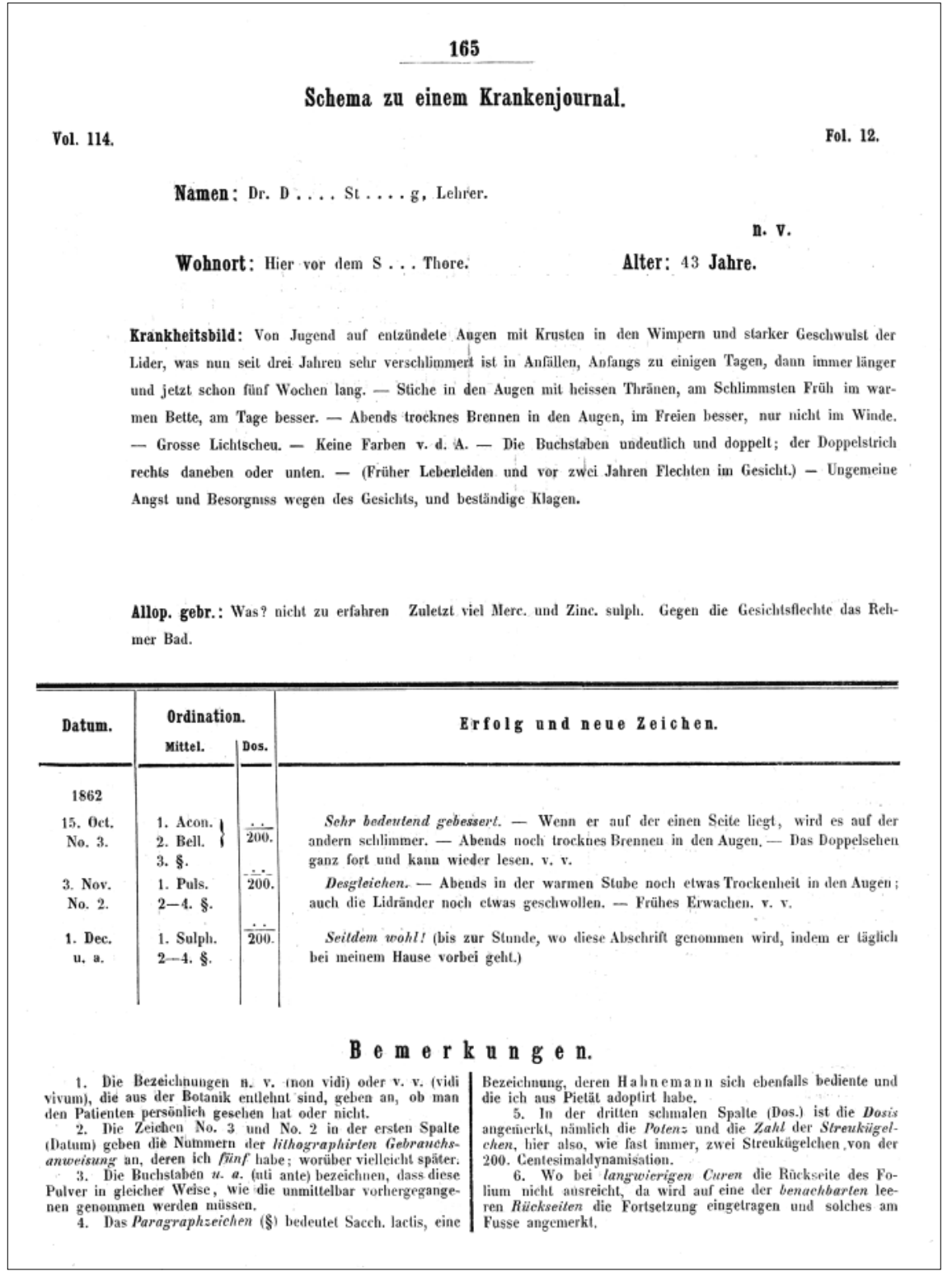

Source: Bönninghausen, n. 10, p. 165. 
With the help of this source, a database was developed, staying very close to the original and, therefore, patient-oriented ${ }^{11}$. It contains several fields giving the socio-statistical information about the sick person, details of his or her first anamnesis and the therapy itself. The database was the main instrument used to gain quantitative access to the mass of information provided through the chosen journals. In fact, it is the sum of the stories of more than 14,200 single patients who visited the homeopath in the years covered by the chosen casebooks, outlining their diseases and their behaviour.

\section{The practice}

When Christine entered the room of Bönninghausen, she probably was not the first patient he had seen on Sunday 26th August 1849. Christine could have chosen from a variety of medical services in Münster. The former seat of a Prince-Bishopric was home to more doctors than most of the smaller towns in the surrounding area ${ }^{12}$. She might even have asked other lay people for medical advice, but, for unknown reasons, Christine decided to see the homeopath and to use his «alternative» therapy. As she talked to Bönninghausen, he would have started noting some general information about her, such as her age, her place of residence, and her marital status. He would continue with the above-mentioned symptoms she was currently complaining about. All this information neatly filled in one page of the journals Bönninghausen kept (see figure 1$)^{13}$.

These records also reveal that, like Christine, three other sick people had decided to visit the practice of the homeopath for the first time on that very day ${ }^{14}$. They came from other towns around Münster. One was a girl aged 17, the other two were men, a 57 year-old priest, and a 52 year-old man of unknown profession who had diarrhoea. As Bönninghausen was seeing all of them for the first time, he might have paid their stories more

11. The database was created with the program FileMaker Pro. For further details see Baschin, n. 3, p. 34-45.

12. See n. 5 .

13. See n. 9 and 10. The original file in IGM, P 73, f. 172 .

14. IGM, P 73, f. 171 to f. 174. 
attention, noticing every detail about their actual status. It was not unusual that a lot of people came to see their doctor on a Sunday ${ }^{15}$.

A total of 59 sick people had seen Bönninghausen for the first time during the month of August and 831 patients did so during 1849. Between 1829 and 1864, an estimated total of 27,500 visited the homeopath at least once, and therefore built up his practice and formed his daily life as a therapist (see table 1$)^{16}$.

The 26th August 1849 was a busy day for Bönninghausen. In addition to the four people already mentioned, others came to continue their treatment ${ }^{17}$. Amongst these patients there was, for example, a 27 year-old woman from Lienen, a town about 30 kilometres from Münster ${ }^{18}$. It was her fourth and last visit to Bönninghausen. The homeopathic therapy had improved her itching in the breast and her aches in the shoulder and head. By the end of the day, Bönninghausen had seen a total of 19 patients and had written down their symptoms and the medication. As a result, Christine had one of 19 consultations on the 26th, one of 203 in the month of August or, considered for the whole year (1849), one of 2,498 patients (see table 1). Compared to other practices in that time, these are quite considerable numbers ${ }^{19}$. Even compared to the average consultation rate per day for

15. This was also the case in other practices. For example: Thümmler, Andrea. Rekonstruktion des Alltags eines thüringischen Arztes im 18. Jahrhundert anhand seines Praxistagebuches 1750-1763 [doctoral thesis]. University of Berlin; 2004, p. 41; Balster, Wolfgang. Medizinische Wissenschaft und ärztliche Praxis im Leben des Bochumer Arztes Karl Arnold Kortum (17451824) [doctoral thesis]. University Bochum; 1990, p. 131-134 and p. 209. In Bönninghausen's practice the day of the week most of his patients normally came to see him was Saturday. Baschin, n. 3, p. 294-296 with further remarks.

16. The sum of all patients based on own counting of all journals stored in IGM, Bestand $P$ 1 - P 116.

17. All of them can be found in the database created for the doctoral thesis, Baschin, n. 3, entering the day in the search field. IGM, P 35, f. 31; P 43, f. 90; P 72, f. 61, f. 176, f. 197, f. 215, f. 216; P 73, f. 54, f. 94, f. 107, f. 118, f. 123, f. 155, f. 156, f. 168, f. 171 to f. 174.

18. IGM, P 72, f. 215. She had seen the homeopath for the first time on 2 nd June 1849, continuing her therapy on 1st and 29th July 1849.

19. The amount of 2,498 consultations for 1849 is to be seen as a minimum. Due to the way Bönninghausen kept his records, only consultations of patients who had their first anamneses during the considered years, could be counted. But other people, who had, for example, seen Bönninghausen during 1848 for the first time, a year that was not chosen, could have easily continued their treatment in 1849. In general the amount of registered consultations was on average 1,092 between 1829 and 1833 (S 1), rose to 3,011 in the years 1839/43 (S 2) and 3,742 in $1849 / 53$ (S 3) and slightly decreased at the end of the practice to 2,675 in 1859/63 (S 4). Baschin, n. 3, p. 284. An unknown allopathic doctor in 1750 had had, for 
1849 in the practice of Bönninghausen, this is a huge amount. Normally, he would have had about eight consultations per day during that year ${ }^{20}$.

Table 1. Being a patient in Bönninghausen's practice - how single decisions acumulate to form the practice

\begin{tabular}{lcc}
\hline \multicolumn{1}{c}{ Bönninghausen's practice (1849) } & First Visits & Consultations \\
\hline Christine & 1 & 1 \\
on 10th August 1849 & 4 & 19 \\
in August 1849 & 59 & 203 \\
in 1849 & 831 & 2.498 \\
\hline
\end{tabular}

Source: Own data based on IGM, Bestand P. Absolute numbers.

As many as four visits by the woman from Lienen, mentioned above, were not too common within the practice. The notes reveal that Christine, the first patient mentioned in this article, only came twice. But even, in this respect, she was not a typical patient. Most of them, about $34 \%$, would only turn up once (see figure 2$)^{21}$. This interesting finding is not uncommon. In the practices of other doctors, the majority of patients came only once. In fact, slightly more sick people came to see Bönninghausen more than

example, 556 patients with 820 consultations on 273 days. Thümmler, n. 15, p. 39. Between 1869 and 1902 the Belgian homeopath Gustave van den Berghe treated 21,340 patients, on average 647 new patients a year or 54 a month. Baal, n. 3, p. 51. The average consultation rate of Bönninghausen is similar to that of the allopathic doctor Kortum: see Balster, n. 15, $\mathrm{p}$ 131. And it is also comparable to the practice of the founder of homeopathy Samuel Hahnemann. However, Bönninghausen never had such a large practice as Hahnemann in Paris. For Hahnemann see the overviews offered in: Dinges, Martin. Arztpraxen 1500-1900. Zum Stand der Forschung. In: Dietrich-Daum; Dinges; Jütte; Roilo, eds., n. 2, p. 23-62, here p. 45. Hahnemann had between four and nine consultations per day during the different times of his practice between 1801 and 1831/32. Jütte, Robert: Samuel Hahnemanns Patientenschaft. In: Dinges, ed. Homöopathie, n. 7, p. 23-45, here p. 27-29.

20. In 1849, Bönninghausen had had 2,498 consultations, and 831 first visits during 317 working days. For further details see Baschin, n. 3, p. 286-288.

21. In total, 4,850 of all 14,266 patients had visited Bönninghausen only once and 3,178 came twice. 
Figure 2. Number of consultations per patient therapy (1829-1864).

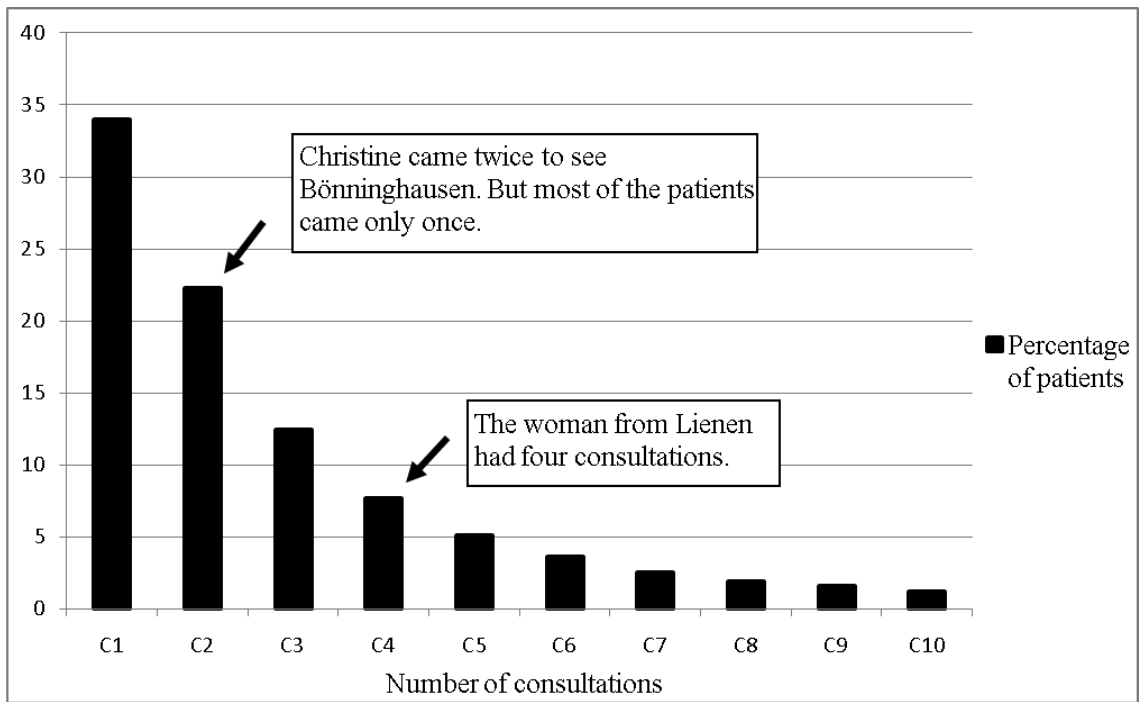

Source: Own data based on IGM, Bestand P. Percentage relative to 14,266 patients.

once than in comparable «allopathic» practices $^{22}$. Therefore, in the majority of cases it was a very short-term treatment that lasted less than a year ${ }^{23}$.

There were, nonetheless, a few patients who continued the therapy for a number of years ${ }^{24}$. For example, an old woman from Münster, who underwent homeopathic treatment from 1830 until she died in 1846, had more than 300 consultations. It is not known which malady led to her first consultation but, during the 16 years of therapy, Bönninghausen gave her medication against premenstrual suffering as well as aches in her breast and

22. One third of Hahnemann's patients came only once and one quarter of van den Berghe's patients have sau their homeopath only once. Schuricht, Ulrich. Samuel Hahnemann. Krankenjournal D16 (1817-1818). Kommentarband zur Transkription. Heidelberg: Haug; 2004, p. 11 and Baal, n. 3, p. 179. Within allopathic practices, these amounts were even higher. See Balster, n. 15, p. 123: 828 of 1382 patients only came once, and 20.4\% (= 282) for a second time; and Thümmler, n. 15, p. 40: out of 556 patients, 409 (73.6\%) came once, 92 twice und 29 three times.

23. 10,285 patients $(72.1 \%)$ finished their therapy within a year.

24. More than ten consultations had about $8 \%(1,095)$ of the patients. 23 patients had 100 and more consultations. Five patients stayed 30 years and more in the homeopathic practice. 
congestion. On average she had seen the homeopath once a month or every second month at least ${ }^{25}$. Some patients also came to see Bönninghausen's son Friedrich, who took over the practice after his father's death in $1864^{26}$. In such cases, one can assume that the homeopathic treatment had convinced them and that they were ready to use it regularly.

\section{The patients}

In general, all sorts of people came to see Bönninghausen seeking a cure for their diseases. The homeopath treated men and women alike, a few day-old babies - his own son for example ${ }^{27}$ - as well as very elderly people - the oldest patient being $97 !^{28}$-, aristocrats and poor people, Protestant Prussian officials as well as Catholic Münsteranian farmers. Most of them had already tried other cures, but in most cases this was without any success or with the symptoms even becoming worse ${ }^{29}$.

Christine had also been ill before, though Bönninghausen did not mention the remedy she had taken ${ }^{30}$. Christine was one of 7,312 women who came to see Bönninghausen. Many of the patients he treated, about $51.3 \%$, were women, but the percentage changed slightly over the years.

25. IGM, P 154 and P 155; P 2, f. 15 (Sanenberg). In her file, 305 consultations are mentioned.

26. In the created database, about 570 patients were mentioned having continued their treatment within the practice of the son after 1864. The «oldest» patient, being treated by Clemens von Bönninghausen since 1830, was a daughter of a «Regierungsrat» (similar to a councillor in Prussian administration) and Bönninghausen did not impart her age, when she consulted him for the first time. IGM, P 154, f. 5.

27. Bönninghausen started homeopathic therapy with his baby son August one day after his birth. IGM, P 154, f. 106.

28. The 97-year-old patient is the oldest one in the database. IGM, P 79, f. 119.

29. For further details see Baschin, n. 3, chapter 4. For 9,851 patients (69.1\%), a former allopathic therapy was mentioned. In 3,377 cases, there were not any notes and only 1,038 people said they had not tried anything before. In fact, the percentage of patients having already used a remedy might even be higher, as people feared to admit it. They were worried that Bönninghausen would not cure them. In 1,177 cases it was pronounced that the former treatments and remedies had not improved the state of the sufferers.

30. As Christine had had some sort of remittent fever («Wechselfieber») she might have taken quinine, a very common remedy used in such cases. Koch, August. Die bewährtesten Hausmittel der Deutschen. Aus den Papieren eines Militärarztes. Leipzig: Voigt 3. edition; 1861, p. 117. 547 patients did admit using this medicine. In some cases, Bönninghausen was able to list all sorts of remedies people had already taken. Some had even been to hospitals or, if they were wealthy, to spas. For more details see Baschin, n. 3, chapter 4. 
For instance, more women came during the early years of the practice and, taking the year $1849,50.4 \%$ of the sick people were female ${ }^{31}$. The young lady was not married, as Bönninghausen says in her file. Unfortunately, the marital status is known for only about $45 \%$ of the patients. Most of them were, like Christine, single when they came to see the homeopath ${ }^{32}$, but there were also couples and families using the service of Bönninghausen ${ }^{33}$.

Christine was, as mentioned before, 24 years old when she came to see Bönninghausen on 26 August 1849. Therefore, her case contributed to the group of patients between 21 and 25 years of age - the age group of most of Bönninghausen's clientele. About $12.0 \%$ of all sick people were in that age group when they saw Bönninghausen for the first time. In the years between 1849 and 1853, slightly more patients, $12.9 \%$, were in this age group (see Figure 3).

The other large group is of toddlers and young children aged up to five years. Bönninghausen treated a lot of children; about $28.6 \%$ of his patients were 18 years or younger ${ }^{34}$.

Christine's father was a tanner ${ }^{35}$. Most of the patients, like her, were members of the lower social class. In fact the number of people from that class rose over the time of his practice. This is quite an amazing result. Obviously people from the lower social class trusted more and more in the homeopathic method during the nineteenth century. After the traditional methods of «academic medicine», mainly consisting of bloodletting and strong laxatives, had failed, the «soft» homeopathic method was given at least one chance ${ }^{36}$. Figure 4 , which presents this fact, turns all the mem-

31. The percentage of female patients within the clientele was $53.2 \%$ in the first years $1829 / 33$ (S 1), decreased to $50.3 \%$ in $1839 / 43$ (S 2), and slightly rose to $51.4(1849 / 53$, S 3 ) respectively 51.6 (1859/64, S 4). Male patients were 30.9\% (1829/33, S 1), 29.0\% (1839/43, S 2), 35.4\% $(1849 / 53$, S 3$)$ and $38.8 \%(1859 / 64$, S 4). The sex of the other patients is unsure. In 1849, 419 (50.4\%) of the 831 patients were female and 303 (36.5\%) male.

32. About $34 \%$ of the all patients were not married (4,892 of 14,266 patients), $10 \%$ were married ( 1.448 persons) and $1 \%$ had been widowed (127 persons). No information on the marital status of 7,797 of the 14,266 patients was available in the database.

33. Further information in Baschin, n. 3, chapter 5.2 .

34. See Baschin, n. 3, p. 135-136 with further reading suggestions. In the practice of the Belgian homeopath, for example, about $16 \%$ of the patients were children. Baal, n. 3, p. 48.

35. For this detail, research was done in the city archives of Münster. Stadtarchiv Münster, Personenkartei Ferdinand Theissing. See also database of the doctoral thesis: Baschin, n. 3, IGM, P 73, f. 172 («Lohgerber»).

36. More details in Baschin, n. 3, chapter 5.1.3. 
Figure 3. Patient age groups in Bönninghausen's practice (1829-1864 [total], 1849-1853 [S 3])

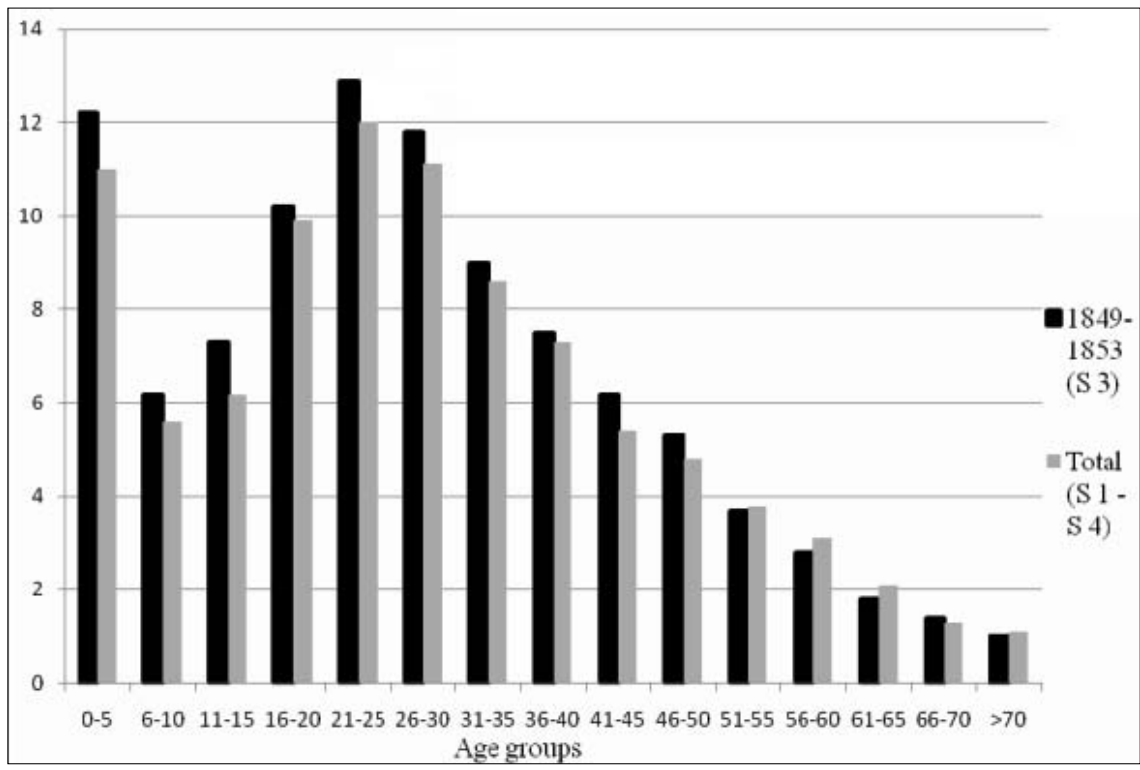

Source: Own data based on IGM, Bestand P. Percentage relative to 14,266 (total) patients and to 4,491 patients (S 3).

bers of this social class into one dark line ${ }^{37}$. Their individual fates are not shown, and Christine contributed through her visit at the practice to this increase in general and to the number of patients from this class in the years between 1849 and 1853 .

Christine lived in Münster, as did 18.2\% of the patients Bönninghausen treated. This was the biggest group of patients living in the same place. In general, most of his patients lived within a radius of 50 kilometres of

37. In total $3.6 \%$ of Bönninghausen's patients were members of the upper class, about $8 \%$ could be seen as middle class and 19.1\% were member of the lower social class. In $184951 \%$ of the city's population were part of the lower class. A further 33.2\% were craftsmen. Shopkeepers and merchants made up 5.9\%, whilst civil servants and the clergy made up 3\% and $0.5 \%$ respectively. In 1843, the military made up $11.3 \%$ of the population. Behr, Hans-Joachim. Zwischen Vormärz und Reichsgründung. In: Jakob ed., n. 5, volume 2, p. 79-129, here p. 79. Even in the original, the figures total only $95.5 \%$, without any reason being given. 
Figure 4. Social class of patients in Bönninghausen's practice (1829-1864)

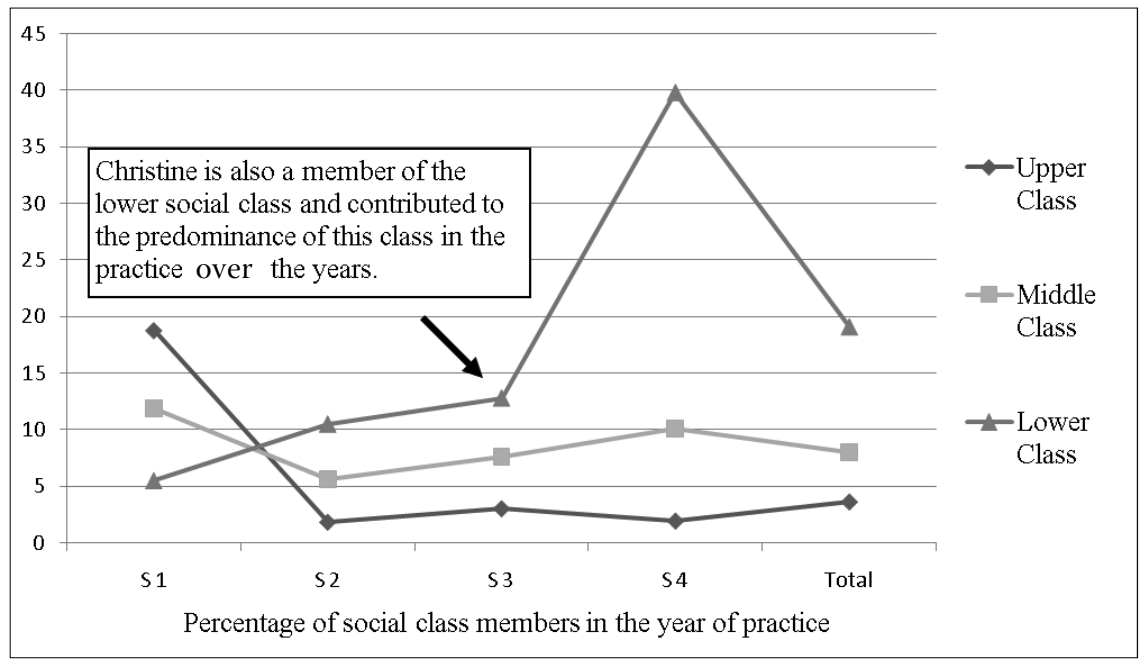

Source: Own data based on IGM, Bestand P. Percentage relative to 14,266 patients (total) and to 1,185 patients (S 1), to 4,524 patients (S 2), to 4,491 patients (S 3) and to 4,066 patients (S 4 ).

Münster, and were therefore easily able to see the homeopath within a day's journey ${ }^{38}$. Thus, Christine represents all the socio-statistical aspects that were typical of the patients who saw Bönninghausen in his practice in the years under study, and she personifies all the average values within the social structure of the clientele.

\section{The illnesses}

Due to the homeopathic method, Bönninghausen did not write diagnoses of illnesses in his journal. Instead he wrote down every single symptom the sick person was complaining about when he or she came into his practice ${ }^{39}$. As mentioned in the introduction, Christine did not suffer from a severe

38. Baschin, n. 3, p. 149. This is the average area of a private medical practice. Jütte, n. 19, p. 39.

39. A description of how a homeopathic anamnesis should be taken in: Hahnemann, Samuel. Organon der Heilkunst. «Aude sapere». Standardausgabe der 6. Auflage. Ed. Josef Schmidt, Stuttgart: Haug; 1999, § 83- § 104. 
illness. She described some premenstrual suffering such as an aching stomach, burning and cutting in her womb. All her complaints were worse when at rest and in the evening. Furthermore her «monthly malady» was too short and too weak. She felt itches in her breasts, and her genital area was very sweaty. Her throat was dry and she was very thirsty. Her left thigh had been stiff and numb for six years. Six years earlier some sort of intermittent fever had confined her to bed for 17 weeks ${ }^{40}$.

Christine was not alone in having these complaints. 38.5\% of all women described problems with their menstruation. Considering all the patients, Christine also shared some symptoms mentioned by most of them. For example, fever conditions («Fieberzustände»), as they were called in a description Bönninghausen had produced, were the most common ailment in the practice ${ }^{41}$. This term not only summarised feverish illnesses but everything that occurred in combination with abnormal feelings of warmth and coolness, or extraordinary sweating ${ }^{42}$. In this case, the sweaty feeling in Christine's genital area was summarised under this heading. Of all the parts of the body, the legs and the feet were the most afflicted. And so was Christine, who had complained of a numb and stiff feeling in her left leg (see table 2$)^{43}$. Fortunately for Christine she had no cough, which was also very common in the practice and she did not say anything about her appetite, as did $23.6 \%$ of the patients ${ }^{44} .22 .3 \%$ of all sick people had problems with their digestion and complained about their excreta («Stuhlausleerungen»).

To sum up, most patients told Bönninghausen about fever conditions («Fieberzustände»), their appetite and eating behaviour, their excreta,

40. IGM, P 73, f. 172. The original notes are: «Vor und Bes. nach der Periode, die zu schwach ist und nur einen Tag dauert, Leibschmerzen, wie Brennen und Schneiden, in der Ruhe und gegen Abend am schl. - trocken im Halse. - Viel Durst. - Steifheit und Gefühllosigkeit des linken Oberschenkels, seit 6 Jahren. - Empfindlichkeit der Schaam. - Schweiß der Sch. und Achselgruben; nicht im Gesichte. - (Vor 6 Jahren lange 17 Wochen lang Wechselfieber) - Stiche in den Brüsten.»

41. 31.7\% of all patients complained about such symptoms.

42. Bönninghausen, Clemens von. Die homöopathische Diät und die Entwerfung eines vollständigen Krankheitsbildes behufs homöopathischer Heilung für das nichtärztliche Publikum. Münster: Regensburg; 1833, p. 38.

43. $20.5 \%$ of all patients had symptoms in legs and feet.

44. About $18.8 \%$ of all patients had cough. 
symptoms concerning their legs and feet as well as a cough (see table 2) ${ }^{45}$. One patient, a 25 year old woman from Glandorf, who came to see the homeopath in 1839 for the first time, complained about symptoms from all those areas ${ }^{46}$. In the evening she had «aches in her thigh», which she described as «like itching twinges». She often had «looseness» and suffered from «sweat, especially of the nose» and «grey cough phlegm». Concerning her eating habits and appetite she said: «bacon produces bile, with fatty taste» ${ }^{47}$. Furthermore she had problems with her menstruation, which had suddenly stopped after a shock, to return «every 14 days with aches in her upper womb and sickness» ${ }^{48}$. It cannot be clearly seen from the additional information whether the homeopathic therapy really improved her condition or not. She came four times in 1839 and then stopped the visits. But in 1856 she returned to Bönninghausen complaining about different illnesses.

Table 2. Groups of most mentioned symptoms in Bönninghausen's practice

\begin{tabular}{cll}
\hline Rank & 1849-1853 (4,491 patients in S 3) & Whole practice (14,266 patients) \\
\hline 1 & Menstruation (female patients only) 49.3\% & Menstruation (female patients only) $38.5 \%$ \\
2 & Fever conditions («Fieberzustände») 43.2\% & Fever conditions («Fieberzustände») 31.7\% \\
3 & Excreta («Stuhlausleerung ») 29.3\% & Appetite 23.6\% \\
4 & Appetite 27.7\% & Excreta («Stuhlausleerung ») $22.3 \%$ \\
5 & Thirst 23.3\% & Legs and feet («Unterglieder») 20.5\% \\
6 & Legs and feet («Unterglieder») 21.7\% & Cough 18.8\% \\
\hline
\end{tabular}

Source: Own data based on IGM, Bestand P. Percentage relative to the total of 14,266 patients and to 4.491 patients in S 3 .

45. In total the complaints mentioned in the first anamnesis were structured by 50 categories. For further information Baschin, n. 3, chapter 6. These categories followed the instruction Bönninghausen himself had given to completely describe the illness suffered. Bönninghausen, ก. 42.

46. IGM, P 37, f. 89. There are a total of 38 patients in the database covering the main five symptom areas in their first anamnesis.

47. The original words in IGM, P 37, f. 89 are: «Nach Schreck erst Menostasie, nun die Per. alle 14 Tage, mit Schmerzen im Oberbauche und Übelkeit. - Abends Schmerz der Oberschenkel, wie juckendes Stechen. - Speck stößt auf, mit fettigem Geschmack. - Oft Durchfall. - Abends im Stehen schlimmer. - Grauen Hustenauswurf. - Schweiß, bes. der Nase».

48. In fact problems with menstruation were the biggest group of symptoms mentioned in the first anamnesis. But as this condition only concerns women, it cannot really be counted for every patient. 
Christine also mentioned that she was very thirsty. Such symptoms became more common, and more people complained about them over the years of practice. Amongst those patients who saw Bönninghausen between 1849 and 1853, complaints concerning thirst were most common in the first anamnesis. About $23.3 \%$ of all the sick people who had seen the homeopath for the first time in these years told him during their anamneses something about their thirst and drinking behaviour ${ }^{49} .21 .5 \%$ of all the patients in the period under consideration complained about coughs, so that this symptom was amongst the six top groups of complaints in Bönninghausen's practice during this period (see table 2$)^{50}$. The first anamneses became longer during the years of practice and contained more symptoms. Taking all 14,266 patients, the notes contained an average of 4.2 symptoms. Over the years under consideration, 1849-1853, the average was $5.1^{51}$.

Considering the spectrum of illnesses, Bönninghausen faced similar diseases and symptoms in his practice to those every other doctor experienced in the nineteenth century. Even compared to symptoms today, coughs, problems with the digestion and feverish feelings are most common in daily medical practice ${ }^{52}$.

\section{Conclusion}

There are two different major methodological approaches in historical research: the quantitative and the qualitative. They seem to contradict each other, as one focuses on individuals or a few cases, whilst the other concentrates on masses or structures. Each of them has certain advantages and disadvantages. One approach uses numbers and a certain general idea

49. During these years, patients complaining about thirst feelings were: 1829/33 (S 1) 1.2\%, 1839/43 (S 2) 9.1\%, 1849/53 (S 3) 23.3\%, 1859/64 (S 4) 23.2\%, total (S 1 - S 4) $16.9 \%$.

50. During these years, the symptom cough was mentioned by $1829 / 33$ (S 1) 10.4\%, 1839/43 (S 2) $19.2 \%, 1849 / 53$ (S 3) $21.5 \%, 1859 / 64$ (S 4) $18.1 \%$, total (S 1 - S 4) $18.8 \%$ of all patients.

51. For the total of 14,266 patients, 59,739 illness symptoms were noted. This means an average of 4.2 symptoms per patient. Between 1849 and 1853 4,491 sick people came to see Bönninghausen and 22,836 symptoms were noted in total.

52. For further information and reading suggestions see Baschin, n. 3, chapter 6.2.1. For the situation in Germany see: Gesundheitsberichterstattung des Bundes. Gesundheitsbericht 1998 [cited 16 Nov 2008]: chapter 3.5 table 3.5.1. Available from: http://www.gbe-bund.de/gbe10/ abrechnung.prc_abr_test_logon?p_uid=gastf\&p_aid=\&p_knoten=FID\&p_sprache=D\&p_suchstring $=832$. 
of a medical practice, and the other offers access to individual lives. Seen literally, this is the difference between statistics and the fate of individuals. A combination of both is not impossible and should lead to interesting results, as has been shown in this article and those by other authors ${ }^{53}$. On the contrary, one could not exist without the other.

Historical research has, in this respect, profited greatly from the technical possibilities now offered by computerisation ${ }^{54}$. Research on the journals of Clemens von Bönninghausen was only possible due to the quantitative access offered by a database ${ }^{55}$. Creating the database is time-consuming, but the research opportunities given afterwards are promising. Not only can statistics be produced for a time where almost no official statistical material was available, but it is possible to demonstrate how individuals built up or formed practices of healers ${ }^{56}$. The researcher is able to link individual fates to statistics in these cases.

Normally, within all of those statistics delivered, for example, in magazines and by official authorities, the fate of the individuals, the sick who form the core of patient history, seems to have vanished. The statistics

53. I am referring specially to the doctoral theses of Anne Hilde van Baal, n. 3. Her methodological approach is very similar to the one used in my dissertation: Baschin, n. 3. She also focuses on the patients, describing the practice of the homeopath van den Berghe through their actions.

54. For example: Imhof, Arthur; Larsen, Øivind, eds. Sozialgeschichte und Medizin. Probleme der quantifizierenden Quellenbearbeitung in der Sozial- und Medizingeschichte. Oslo/Stuttgart: Univ.-Forl./Fischer; 1976 (Medizin in Geschichte und Kultur 12); and Porter, Roy; Wear, Andrew, eds. Problems and methods in the history of medicine. London/New York/Sydney: Croom Helm; 1987.

55. Balster, n. 15, p. 85-86; Duffin, n. 2, p. 5; Eckart; Jütte, n. 1, p. 183-184; Imhof; Larsen, eds., n. 54, p. 99-105; Roilo, Christine. «Historiae Morborum» des Franz v. Ottenthal. Ein Zwischenbericht. Medizin, Gesellschaft und Geschichte. 1999; 18: 57-80. During a research project at the University of Innsbruck a huge database was constructed, which can now be used for further research projects. See: University Innsbruck. Historiae morborum. Die Krankengeschichten des Franz von Ottenthal (1818-1899). [updated 20 February 2008; cited 14 September 2009]. Available from http://www.uibk.ac.at/ottenthal/. See also Baschin, n. 3, chapter 2 with further reading suggestions.

56. Statistical material in Germany is only common from the 1870s onwards. But in most cases, these statistics only cover some aspects of the health care system, such as mortality rates or the rates of doctors per inhabitant. See: Scholz, Rembrandt. Lebensverlängerungsprozeß und Veränderung der Todesursachenstruktur in Deutschland. In: Imhof, Arthur, ed. Lebenserwartung in Deutschland, Norwegen und Schweden im 19. und 20. Jahrhundert. Berlin: AkademieVerlag; 1994, p. 141-157; Fischer, Wolfram; Kunz, Andreas eds. Grundlagen der Historischen Statistik von Deutschland. Quellen, Methoden, Forschungsziele. Opladen: Westdeutscher Verlag; 1991. 
produced, especially in the case of the journals, only exist as the sum of the individual actions. That is why working with such records offers particular possibilities in order to combine the quantitative aspects of research work with qualitative examples of individual fates ${ }^{57}$.

Through their decision to see Clemens Maria Franz von Bönninghausen at least once his patients built up his practice. By their actions, they shaped the days of the homeopath and left their traces in history. Their turning up at the house of Bönninghausen in Münster seeking treatment allowed the homeopath to register their visit in his casebooks. These casebooks give us the opportunity to rebuild pictures of the sick in the past and their behaviour as well as to study the practice of Bönninghausen.

This presentation of the practice of a lay homeopath, which has only concentrated on some aspects of the rich source the journals offer, has shown that there is no quantity without quality, no statistics without individual fate. Both quantitative and qualitative methods have to be combined to present all aspects of patient history. By considering the individuals' fates within the statistics, which is possible through the source of the patient records, the diagrams and tables gain life and become much more than numbers or lines.

\section{Acknowledgements}

I am thankful to Professor Esteban Rodríguez Ocaña for having kindly invited me to submit this article to Dynamis, and to the organisers of the Conference «Methods in Theory and Practice» of the Wellcome Trust Centre for the History of Medicine at UCL for having given me the chance to

57. Further advantages of the source of patient journals are discussed in: Shephard, David. The casebook, the daybook, and the diary as sources in medical historiography. Canadian Bulletin of Medical History 2000; 17: 245-255; Imhof; Larsen, eds., n. 55, p. 198; Warner, John. The uses of patient records by historians. Patterns, possibilities and perplexities. Health and History. 1999; 1: 101-111; Risse, Guenter; Warner, John. Reconstructing clinical activities. Patient records in medical history. Social History of Medicine. 1992; 5: 183-205; Larsen, Øivind. Case histories in nineteenth-century hospitals. What do they tell the historians? Some methodological considerations with special reference to McKeown's criticism of medicine. Medizin, Gesellschaft und Geschichte. 1991, 10: 127-148; Hoffmann-Richter, Ulrike; Finzen, Asmus. Die Krankengeschichte als Quelle. Zur Nutzung der Krankengeschichte als Quelle für Wissenschaft und psychiatrischen Alltag. Bios. 1998; 11: 280-297; Dinges, n. 19, p. 38-46; Baal, n. 3, p. 8; Roilo, n. 55, p. 64. 
present my doctoral thesis before an international audience. This article is for my grandparents who would have loved to learn English properly, but who were prevented from doing so. 